\title{
Analysis of selected technological properties of green sands with starch-based additives
}

\author{
Analiza wybranych właściwości technologicznych \\ klasycznych mas formierskich z dodatkami skrobiowymi
}

\begin{abstract}
This paper presents the results of determining the effect of the addition of native starch and mineral-starch mixes on selected technological properties of sands. The study was carried out on the permeability, compressive strength, and wear resistance of molding. Green sand with bentonite and silica sand was compared to green sand with the addition of Superior Standard native starch or the addition of a mineral-starch composition in the form of binder Albertine F/1. The main difference in applied starch materials is the characteristic property of native starch which is insoluble in cold water. Therefore, it was difficult to bond water added to molding sand during mixing of the ingredients in this case. However, the Albertine F/1 starch-based binder is a mixture of starch and aluminosilicates, whereas the bonding of water added into molding sand during ingredient mixing is more efficient.
\end{abstract}

Keywords: green sand system, starch additives, green compressive strength, permeability, wear resistance

\section{Streszczenie}

W artykule przedstawiono wyniki przeprowadzonych badań, które miały na celu określenie wpływu dodatku skrobi natywnej i mieszanek skrobiowo-mineralnych do klasycznych mas formierskich na ich wybrane właściwości technologiczne. Przeprowadzone zostały badania dotyczące przepuszczalności, wytrzymałości na ściskanie oraz osypliwości mas formierskich. Masę wyjściową stanowiła masa z bentonitem na osnowie piasku kwarcowego, którą porównano z masami z dodatkiem skrobi natywnej Superior Standard oraz z dodatkiem komercyjnego spoiwa skrobiowo-mineralnego Albertine F/1. Cechą różnicującą zastosowanych materiałów skrobiowych jest to, że skrobia natywna nie rozpuszcza się w zimnej wodzie, więc w jej przypadku utrudnione jest wiązanie wody wprowadzonej do masy podczas mieszania składników. Natomiast spoiwo

Dariusz Drożyński Ph.D., Żaneta Kurleto M.Sc. Eng., Karolina Kaczmarska M.Sc. Eng., Beata Grabowska Ph.D.: AGH University of Science and Technology, Faculty of Foundry Engineering, Krakow, Poland; dd@agh.edu.pl 
skrobiowe Albertine F/1 jest mieszaniną skrobi i glinokrzemianów, dzięki czemu wiązanie wody wprowadzonej do masy podczas mieszania składników okazuje się bardziej wydajne.

Słowa kluczowe: klasyczna masa formierska, dodatki skrobiowe, wytrzymałość na ściskanie w stanie wilgotnym, przepuszczalność, osypliwość

\section{Introduction}

The application of starch in its native form as a main binder in molding sand technology as a main combining material is not common due to its physicochemical properties [1]. In the foundry industry, native starch is currently used as an additive to molding sands in order to improve their strength and hardness [2,3]. On the other hand, the presence of starch in the composition of molding causes weaker molding flowability, lower resistance to the penetration of metal into the mold, and lower erosion resistance [1]. This is due to the fact that it is insoluble in cold water [4]. Partially dissolving native starch in water occurs only at the temperature of about $70^{\circ} \mathrm{C}[5,6]$. At this temperature starch begins to swell. Therefore, when the ingredients mix at ambient temperatures, the starch binder does not efficiently absorb water, introduced into the sand grains. In the case of Albertine $\mathrm{F} / 1$ binder (which consists of a starch and mineral material mixture), it is observed that water is bonded better than native starch [6]. In addition, many publications indicate that only modified starch is characterized by higher solubility in cold water, which may result in a positive effect in applying it to green sand systems [6].

The main purpose of this research was to study and compare the impact of selected starch additives (including a starch-mineral mixture) on selected technological properties of green sands.

\section{Materials}

In this study, the sand matrix in the form of silica sand by SIBELCO EUROPE (BK D 0.16 - $0.32 \mathrm{MM}$ ) was used. The main binding material was activated bentonite "Specjal" (ZGM Zębiec). As additives, the following products were applied:

- binder Albertine F/1 starch-aluminosilicate produced by Hüttenes Albertus, with humidity at a level of $12 \%(\mathrm{pH} 4.5)$;

- the native starch type Superior Standard produced by "TRZEMESZNO" Ltd. Potato Industry Company, with humidity at a level of 15,5\% (pH 7.3).

\section{Methodology}

In order to determine the influence of starch additives on the properties of green sands, numerous studies on the properties of molding sands have been conducted (which are partly presented in this article). Investigated molding sands consisted of (in parts by 
weight): quartz sand - 100, bentonite "Specjal" - 6.0; starch binder Albertine F/1 - 1.0; or native starch -1.0. For comparison, tests were performed on green sand without the addition of the above-mentioned starch-based binders.

Conducting research on the technological properties proceeded according to the following standards:

- measurement of permeability: $P^{w} \mathrm{PN}-80 / \mathrm{H}-11072$,

- measurement of green compressive strength: $R_{c}^{w} \mathrm{PN}-83 / \mathrm{H}-11073$,

- measurement of wear resistance $S: B N-77 / 4024-02$.

During measurements, relative humidity in the laboratory was within the range of $35-48 \%$ and the temperature within the range of $23-25^{\circ} \mathrm{C}$.

\section{Results and discussion}

The results of our research on the starch-binder addition to green sands are shown in Figures 1-3.

Figure 1 presents the results of the effect of water content on permeability. For all investigated molding sands, a similar course of permeability changes is observed (i.e., an increase in water content causes an increase in permeability to achieve the maximum; then, a decrease in permeability is noticed). The permeability maximum is observed for all three cases in green sands with a moisture content of about $2 \%$.

The course of the curves shown in Figure 1 indicates that the addition of native starch adversely affects permeability. However, the addition of Albertine F/1 causes an increase in the permeability value and shifts the maximum and whole characteristics to a higher water content.

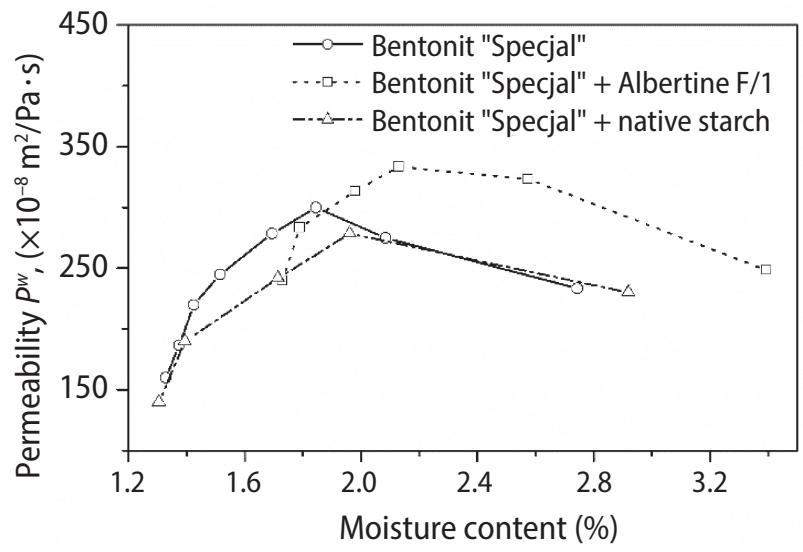

Fig. 1. The influence of moisture content on permeability $P^{w}$ in green sands consisting of (parts by weight): silica sand - 100; bentonite "Specjal" - 6.0 - Basic green sand and the of additives: Albertine F/1-1.0 or native starch -1.0 
Figure 2 presents the influence of water content on its green compressive strength for tested molding sands (basic green sand and green sand with the addition of a starch binder). The obtained results allow us to conclude that the addition of native starch has a negative influence on green-compressive-strength molding sand bonded by bentonite. In the case of molding sand with the addition of native starch, the maximum green compressive strength of $0.16 \mathrm{MPa}$ is present at a relative humidity of $1.7 \%$, and this is less than the maximum strength obtained for green sand without the addition of starch $(0.17 \mathrm{MPa}$ ) at a moisture content of about $1.5 \%$. However, the introduction of 1.0 part per weight of Albertine $\mathrm{F} / 1$ binder to the molding sand causes a decrease in green-compressive-strength values of about $35 \%$ ( $0.11 \mathrm{MPa}$ at a moisture content of $1.8 \%)$.

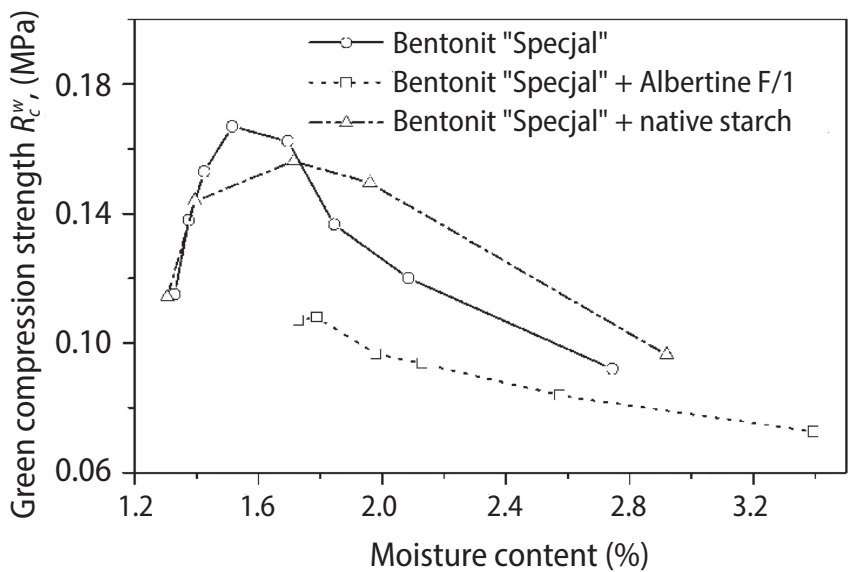

Fig. 2. The influence of moisture content on green compressive strength $R_{c}^{w}$ in green sands consisting of (parts by weight): silica sand - 100; bentonite "Specjal" - 6.0 - Basic green sand and the of additives: Albertine F/1 - 1.0 or native starch -1.0

Figure 3 shows the results of the effect of moisture content on wear resistance for the tested green sand configurations (molding sands with or without starch-binder additives). The obtained results of wear resistance changes suggest that the addition of the Albertine F/1 starch binder to molding sand has the best influence on this property, because it results in an improvement of the wear resistance value throughout the whole range of moisture content. However, green sand with the addition of native starch behaves similarly to molding sand without a binder addition. Figure 3 shows the results of the effect of moisture content on wear resistance for the tested green sand configurations (molding sands with or without starch-binder additives). The obtained results of wear resistance changes suggest that the addition of the Albertine F/1 starch binder to molding sand has the best influence on this property, because it results in an 
improvement of the wear resistance value throughout the whole range of moisture content. However, green sand with the addition of native starch behaves similarly to molding sand without a binder addition.

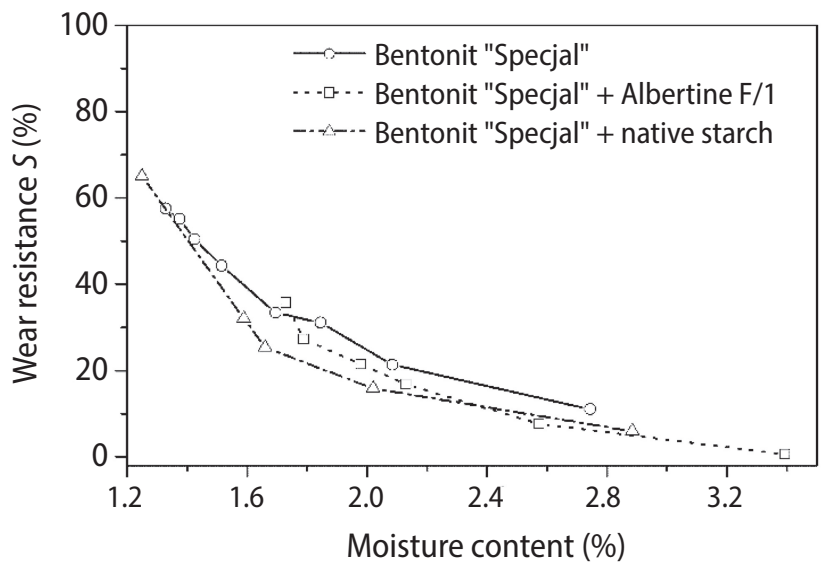

Fig. 3. The influence of moisture content on wear resistance $S$ in green sands consisting of (parts by weight): silica sand - 100; bentonite "Specjal" - 6.0 - Basic green sand and the of additives: Albertine F/1 - 1.0 or native starch -1.0

\section{Conclusion}

On the basis of the conducted measurements presented in this article, it can be concluded that the introduced starch additives have different effects on selected properties of green sand systems, including:

- the addition of native starch has a far-better effect on green compressive strength (as compared to binders containing starch and aluminosilicates such as Albertine F/1). $R_{c}^{w}$ values for the addition of native starch are about $30 \%$ higher than the weight of binder Albertine F/1;

- the addition of starch-mineral binder Albertine $F / 1$ has a positive effect on permeability. The resulting permeability values of green sand with the addition of starch binder Albertine $\mathrm{F} / 1$ are higher than green sand with and without native starch additives;

- the addition of starch binder Albertine F/1 also has a positive effect on the wear resistance of molding sand. In the case of green sand with Albertine F/1, the wear resistance value at a relative humidity of $2.5 \%$ is almost two times better than green sand containing native starch.

\section{Acknowledgement}

The work was supported by the Project AGH No. 11.11.170.318/13. 


\section{References}

[1] Lewandowski J.L.: Tworzywa na formy odlewnicze. Wydawnictwo Naukowe AKAPIT, Kraków,1997

[2] Zhou X., Yang J., Qian F., Qu G.: Synthesis and Application of Modified Starch as a Shell-Core Main Adhesive in a Foundry. Journal of Applied Polymer Science, 116 (2010), 2893-2900

[3] Grabowska B.: Nowe spoiwa polimerowe w postaci wodnych kompozycji z udziałem poli(kwasu akrylowego) lub jego soli i modyfikowanego biopolimeru. Wydawnictwo Naukowe AKAPIT, Kraków, 2013

[4] Kaczmarska K., Grabowska B.: Analysis of structural changes in the starch-based binder cross-linked by physical agents. Archives of Foundry Engineering, 13 (2013), 51-56

[5] Kaczmarska K., Grabowska B.: Biodegradation of a new polymer binder based on modified starch in a water environment. Metallurgy and Foundry Engineering, 40, 1 (2014), 7-14

[6] Kaczmarska K., Grabowska B., Drożyński D.: Analysis of the selected properties of microwave-cured moulding sands with starch-based binders. Archives of Foundry Engineering, 14 (2014), 5-52 